\title{
Owning memories: a tale of two cities
}

\author{
Anna Catalani University of Lincoln, United Kingdom acatalani@lincoln.ac.uk \\ Pam Panas University of Salford, United Kingdom p.panas@salford.ac.uk
}

In 1894 Queen Victoria opened the Salford Docks, now known as Salford Quays, home of MediaCityUK. At the time, Salford Docks were considered a masterpiece of engineering, allowing Manchester to circumvent the route through Liverpool and have access to international trade. The area was an ambitious hub for commerce, industrial activity and job prospects. Although more than 100 years have passed, Salford Quays is again under the spotlight and has the ambition to be a contemporary contender in the cultural industries market - this time focussing, through MediacityUK, on moving the media industry away from London. In order to attract such a prestigious focus, the developers have responded by building waterside apartments, luxury housing and speedy infrastructure and by promoting a successful professional lifestyle, with cultural and cutting-edge designer events. However, the local community seems to be more than ever alienated from this process, the sense of cultural collective memory being diluted. Throughout this paper, we are considering issues relating both to the historical significance of Salford Quays as well as to its cultural legacy within the local community. In order to do so, we are addressing the following research questions: How can the past be brought to into the present to support a sense of identity cohesion? Can Salford shake off the image of a derelict area and become the innovative creative quarter, through the (living) memories of its community? We will argue that the reinvention of Salford Quays as a new cutting-edge creative quarter happens at the expense of the historical memory of the place. In this way, local people and local memories do not become an integral part of the regeneration strategy, but are almost erased from the whole process.

(C) 2014 Green Lines Instituto para o Desenvolvimento Sustentável. All rights reserved.

Keywords: local heritage, collective memories, regeneration, identity cohesion.

\section{Introduction}

In 2011, the British Broadcasting Corporation (BBC) relocated, in part, from London to Salford, one of the most economically deprived areas of the United Kingdom (Fitzgerald, 2012) At a national level, the relocation was an 'endeavour to shape a BBC [...], less focused on London and more representative of, and engaged with, the rest of the country' (Christophers, 2008: 2313). At a regional level, the move was yet another attempt of the local government to foster Salford's urban development agenda that, through a creative growth, should have also opened up opportunities for local, economical and cultural growth. Indeed, as a representative of the Central Salford Urban Regeneration Company stated, it was hoped that Salford would be made into 'a beautiful, vibrant and prosperous city, where people will want to live, work and study for generations to come' (Salford City Council, 2005). However, three years since the BBC's relocation and almost twenty years since the start of the urban regeneration strategy, Salford still is an area dominated by urban inequalities and with only a restricted group of individuals involved in and benefiting from the creative growth.

Some of the regeneration strategies involve gentrification of the area. The term 'gentrification' - coined by Ruth Glass (1964) in the mid-twentieth century- entails, first of all, class inequalities. It also unjustly prioritises the capitalist interest on profitable land markets with policies that do not benefit the original population (Slater, 2011). Whilst Anna Minton's research on various waterfront sites around Britain talks of 'regeneration' primarily in terms of 'renaissance', this seems also to be a politically-loaded term, 
using Urban Development Corporations to revitalise docklands so that the sites can attract and benefit from a more affluent, professional class (Minton, 2009).

Accordingly, Saskia Sassen adds that gentrification,

'was initially understood as the rehabilitation of decaying and low income housing by middle-class outsiders.[However] by the 1980's new scholarship had developed a far broader meaning of gentrification, linking it with processes of spatial, economic and social restructuring' (1991; 255).

In Salford Docklands, regeneration obliterated any connotation of the site's original use. It renamed and publicised its identity, through the branding and marketing of Salford Quays. When the site successfully attracted the BBC (and later the Granada Studios), the area was further promoted with the additional brand of 'MediaCityUK' onto the site. With this research, we wanted to investigate how this was felt by local residents; at the same time we aimed to demonstrate the importance of the (cultural) contestation taking place, when previously ignored ex-industrial sites are revitalised according to prescriptive and marketed sterilization of the previously redundant post-industrial phase (Doron, 2000). The drive to build over an immensely engrained historical past - which could be uncovered in our older subjects' memories - denies their importance, and points to their powerlessness from the process of gentrification by transforming the area into a place of consumption for a far wealthier clientele.

This paper looks at the Salfordian cultural identity and at the hidden discourse of local, collective memory. It aims to make a set of critical observations towards the urban regeneration strategy implemented in Salford. We believe that this (almost aggressive) regeneration strategy risks to obliterate the local history and memory, by reducing Salford Quay to a site of corporate dictatorship and by further rendering impotent the working class in the part they played in the success of their city's history.

We have structured the paper into three main parts: in the first part, we define the historical and social context of Salford Quays, starting from its formal opening in 1894 until its recent development as a media and creative quarter; in the second part, we consider the cultural and social impact the these changes have had on the local community. In the final section, we argue that ignoring Salford's local history and heritage in such a push to promote a shiny new venture, not only does not lead to social cohesion, but also erases the local sense of historical and collective memory.

\section{Salford Quays: a short historical and social overview}

More than any other city in England, Salford has both benefited and suffered of the Industrial Revolution. A typical city of rural England (at least until the 18th century, before changing its status to industrial city), throughout the centuries, Salford had developed under the shadow of Manchester and was granted the city status only in 1926. Salford grew out from the amalgamation of other three smaller towns (Broughton, Pendleton and Salford), all of Anglo-Saxon origins. Salford's name itself is most probably Anglo-Saxon, meaning 'the ford by the willow'1 ${ }^{1}$.

Before the rise of the cotton industry, which saw Manchester overshadowing Salford as the 'commercial capital of the textile region' (Tomlinson 1974: 19), the city of Salford had its fair share of businesses, trading wools and flax, through London. However, the opening of the Ship Canal on the $21^{\text {st }}$ May 1894 by Queen Victoria was a turning point for Salford. The Ship Canal was a $58 \mathrm{~km}$ long inland waterway connecting Liverpool to Manchester. Its purpose was to provide costal and ocean-going boats with direct access to Manchester. The Ship Canal included nine upper docks, four of which (numbered 9,8,7 and 6) were based in Salford. After a slow start, the Ship Canal Company began to prosper and by the late $19^{\text {th }}$ century, 'there were 35 steamship companies with regular services to Salford docks and with agencies in the city' (Bergin, et al. 1975: 72). This commercial prosperity lasted until the late 1970s, when unfortunately the docks began to decline rapidly, due to the increasing size of boats navigating the canal, as well as due to the increased trading activities with Europe and the East. In 1982, Salford docks were officially closed and the area became derelict, until the entrepreneurial turn of the late 1990s, with the regeneration project of the Quays.

Views from Central Government during the 1980's were that Salford was ready to work with the private sector - in comparison to Manchester who, they felt, proved more 'socialist' in outlook. Thus, Salford had been successful in attracting city council grants, which helped development of Salford Quays (Robson, 2002). In 1981, a substantial part of Salford docklands was declared an Enterprise Zone (Gray, 2000). In 1983 Peel Holdings plc acquired Bridgewater Estates: their portfolio included 12,000 acres of land in Manchester and Salford, covering the area of Salford Docklands (Peel Holdings Group, 2014; North West Tourist Board, 1993)'. By 1985, there was a full 'Salford Quays Development Plan', which was to improve infrastructures and the environment including, water, roads, public access and landscape of the docklands area. With this completed by 1990, it was flagship architecture that hailed the new site.

Initially, in 1988 the area was conceived as the home for new and cutting-edge art centres. Salford City Council commissioned internationally renowned architects James Stirling and Michael Wilford to work 
on the project. However, Stirling died in 1992, leaving Wilford to complete the commission in 2000. The Lowry Museum and Gallery opened in 2000, moving the Lowry Collection out of Salford Museum and Art Gaallery into the multi-cultural, art venue in the new Salford Quays ${ }^{3}$. A few years later, in 2007, Holdings plc was granted planning permission for MediaCityUK, the largest purpose-built media community in Europe.

Sitting behind The Lowry on the Manchester Ship Canal, the Imperial War Museum North (designed by Daniel Libeskind and opened in 2001) dominates the contemporary scenery (Fig. 1).

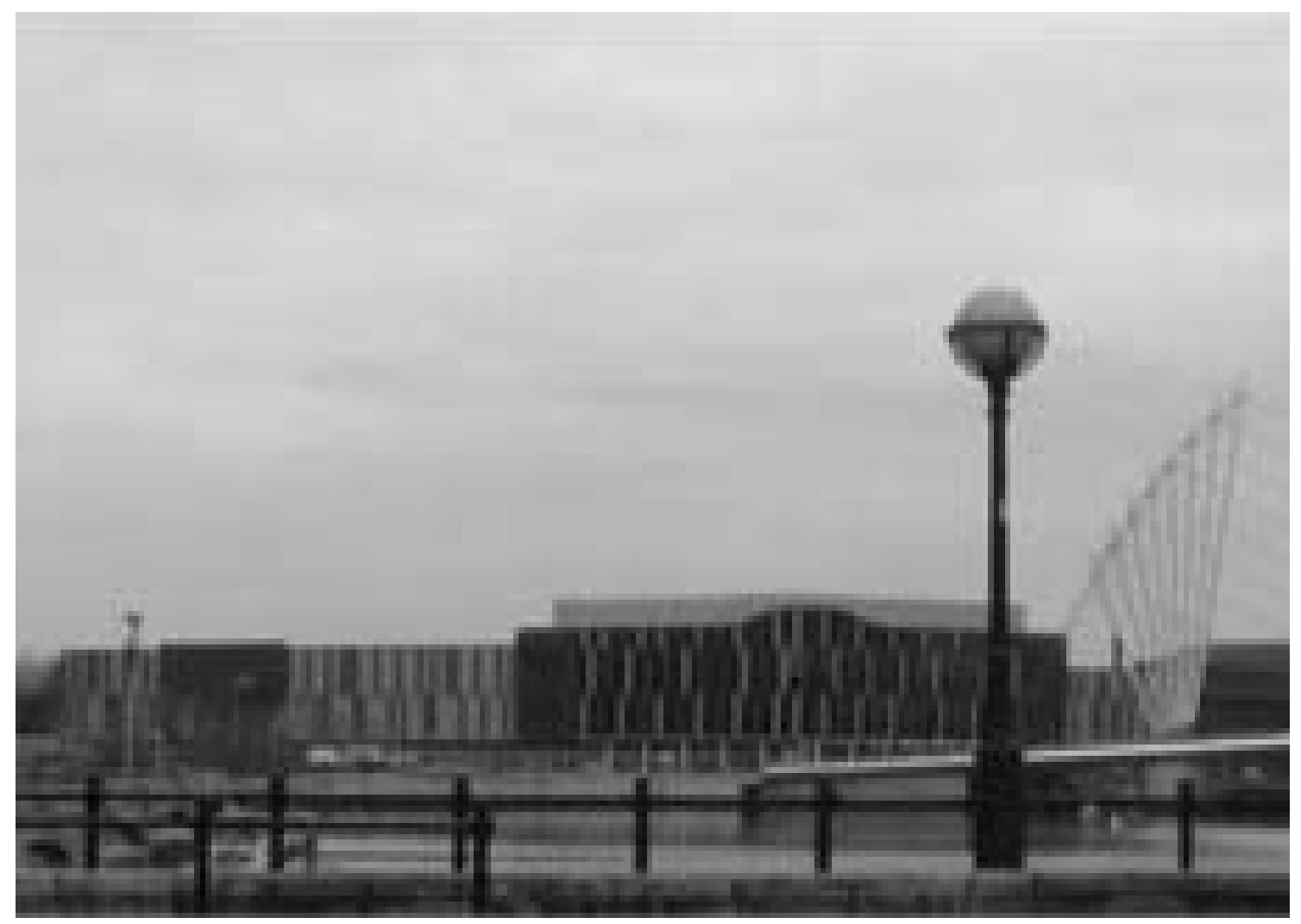

Figure 1. View of the Imperial War Museum (author's own image).

Conceptually designed to represent the world shattered by conflict, the building's disorientating form is made up of shards - 'a globe shattered', in the words of Libeskind (Wheeler and Carson, 2005; Shaw et al., 2008). Visitors can climb the 'Air Shard' (a jagged shaped viewing platform on the top floor of the museum) to view the districts of Trafford and Salford or look through the mesh floor to see how far the ground below lies. From there, they are privileged to experience the spectacular views of MediaCityUK, the Quays and Manchester and at the same time, they are reminded of the incredible transformations that the area has gone through during the last century (Manchester City Council, 1994; Marketing Manchester, 2003).

This cultural and social transformation of the area continued until very recently, with the opening in 2001 of the Lowry Outlet Mall (known as 'The Quays'). However, Peel Holdings Group purchased the Lowry Outlet Mall in 2012 hoping to bring the dismal and frequently failing retail units into their more successfully media orientated scheme. The Group's website also publicises and stresses their strong relationship with the 'community', by having donated $£ 12.5$ million to the Imperial War Museum North (Peel Holdings Group, 2014; Hough, 2012). In 2011 amongst much publicity there was the move of the University of Salford in the MediaCityUK's premises. What were once the docks of one of the most important British ship canals, a symbol of industrial revolution, have now become impressive architectural buildings and shopping hubs (Figs. 2, 3), which visually induce one to forget the cultural history and memory of the place. As the sociologist Paul Connerton explains, this 'culturally induced forgetting is reinforced by the temporality of consumption' (2009: 53), which almost annihilates what was and had taken place. However, in this paper, we are interested in investigating this forgotten and hidden discourse of the local Salfordian, collective memory: we intend (or at least we attempt) to unravel the 'historical' experiences and memories of contemporary Salfordians that could only enrich and shape this cultural and creative transformation. 


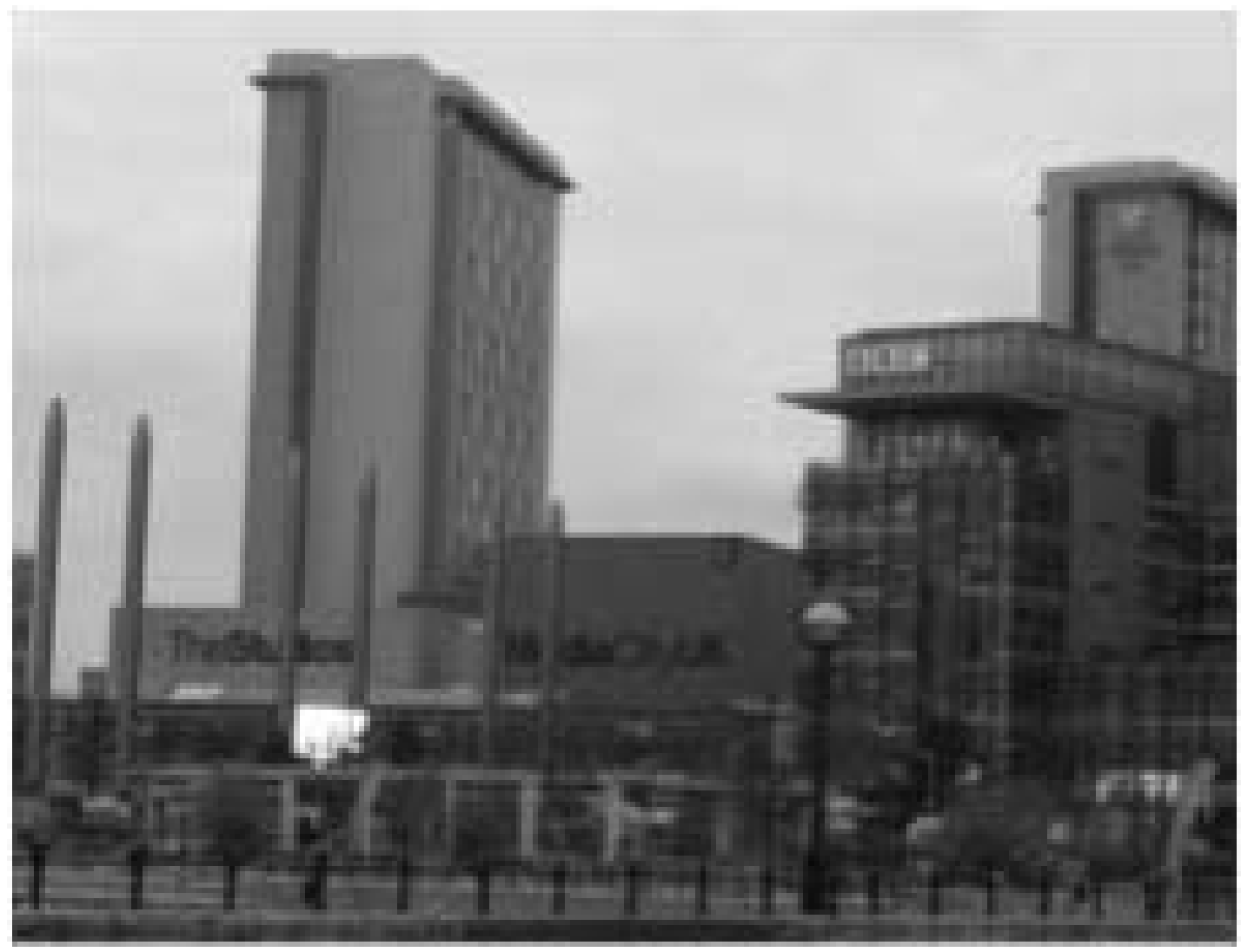

Figure 2. View of MediacityUK premises (author's own image).

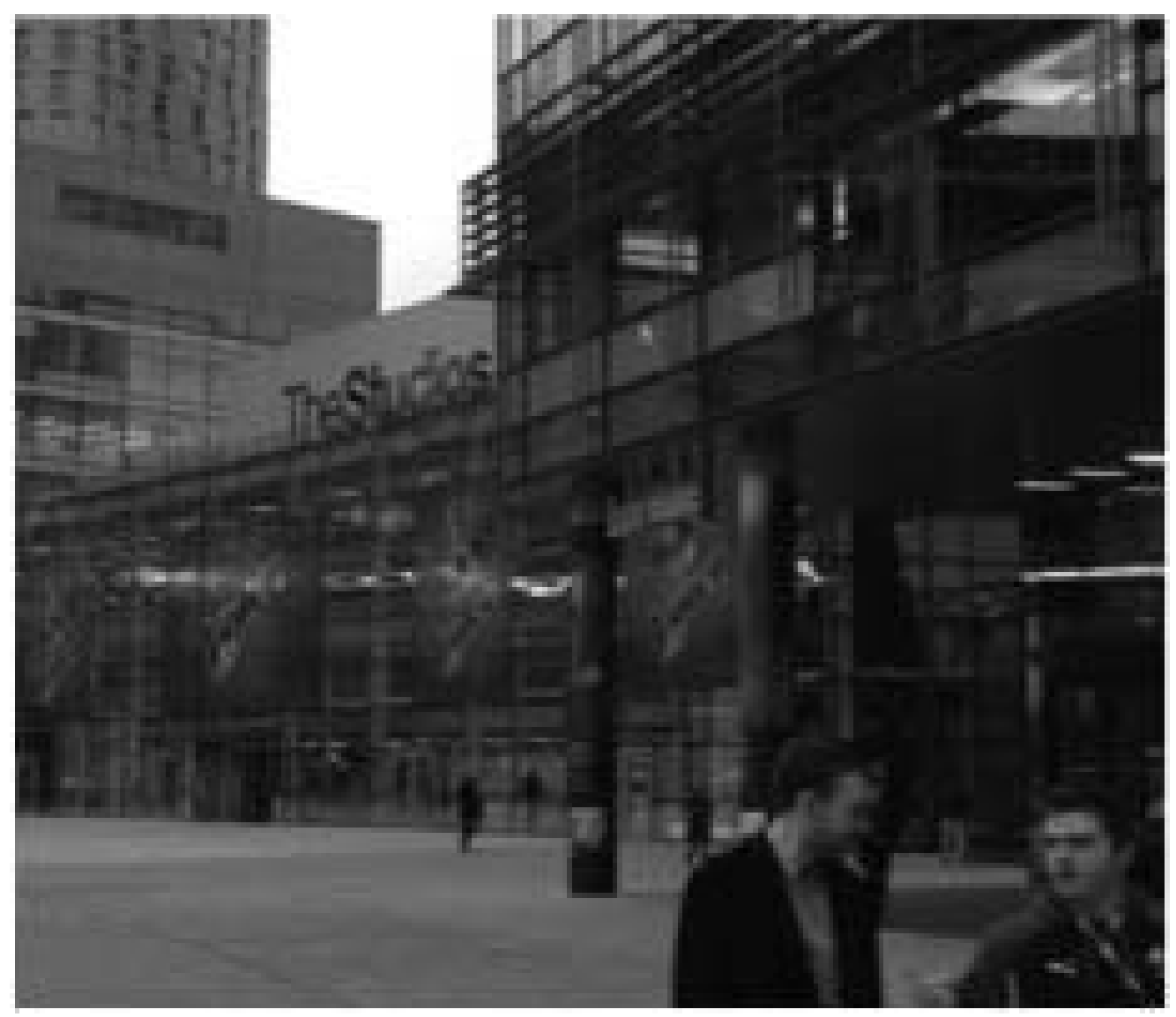

Figure 3. Entrance of The Studios, MediacityUK (author's own image). 
Nowadays Salford's demographic is rather assorted. Together with local working class people - who have been living in the area for a long time - there is also a new group of wealthier and business-like individuals who - thanks to the cultural and economical regeneration - have only just relocated to Salford (particularly to Salford Quays) and are now part of the local life as well as of the social dynamics. The encounter of these different groups, with often antithetical perceptions of the area, is very interesting especially in terms of local heritage and memory construction (Benson and Jackson, 2013). Local Salfordian heritage (being the Victorian docks, the $19^{\text {th }}$ century mills or Cross Lane with its many alehouses or the factories destroyed by the Second World War blitz) has developed in Salford Quays throughout the past 200 years. It has come to represent a 'specific human condition [e.g. the dockland workers, the industrial power or even the recession and job losses] rather than as a single movement or personal project' or a site (Harvey, 2001: 320). However, because of this association with a specific human condition, this heritage bears different understandings, according to the cultural and social group.

As previous studies show, of all social groups, the working class has a very strong emotional reaction associated with heritage sites and local buildings (Watson, 2005; Wedgwood, 2009). This is probably because working class feels that they need to prove themselves as people with a long history and a web of traditions connected with local places/heritage and that there is more to them than just hard labour, job insecurity and low-wage workers. Particularly, within the context of this emotional relation, certain landmarks and (by-gone) buildings may be the symbols of endurance of the local group against social problems as well as the symbol of ancestors' daily lives, and community cohesion. In the next section of the paper, we are going to look more in detail into these now disappeared/ing symbols of endurance and by gone community life.

\section{'Docks, boats,fishing club': the Salford Quays that do not exist anymore}

In order to start to understand the impact that these cultural and social changes have had on the local community, as well as the kind of collective memories and sense of collective identity that had been lost in name of this creative regeneration, 16 semi-structured, short interviews were carried out between October and November 2013 in the area of Salford Quays and at a community café near a university campus in Salford M3 district. Research participants were chosen primarily on the basis of their geographical provenance: they should have been born in Salford or be local people who had been living or should have lived in the area around Salford Quays for the past 30 years, at least. This was a key requirement because we wanted individuals who were, or had been, experiencing the area throughout time and had somehow been affected by the transformation that had taken place.

The age of the interviewees ranged from 30 to 82 years old, with seven of the participants being male and nine female. The interview questions were organised around three main points: the understanding of Salford Docks (and the difference from Salford Quays); the changes and the perception of the transformation that had taken place in the area during the past 30 years and finally the memories associated with the docks (or with the area pre-transformation). From the interviews, two main themes emerged: 'Different ages, different Quays' and 'Family and bygone trades'.

\section{Different ages, different Quays}

The first theme identified was the one of 'Different ages, different Quays'. Due to the wide age spectrum, it was evident that the area was defined (and remembered) differently by different participants. Particularly, older interviewees were unanimous in knowing and calling the area by its original name ('The Docks'), which was strongly associated with the heritage of the area, the worrying years of the 80s recession and with the type of trades taking place before the regeneration (Bergin et al., 1975). Indeed, as one of the interviewees explained, 'I call it the docks, where the Manchester liners used to go in, also ships unloading goods' (F69 M44); this was echoed by another participant who explained: 'Quays. It sounds nicer. Docks sounds worrying. It conjures up thoughts of industrial area, wasteland and pubs that are not nice' (M50 M6). However, interviewees also (almost nostalgically) acknowledged the scale of changes that had happened during the past 40 years and which had not only renovated Salford Docks, but also transformed it. For example, F62 BL3 said: 'I call it Salford Quays because it does not resemble the Docks I knew'. Similarly F68 M27 stated that he calls it 'the Quays, because it is updated and it becomes a different place'.

The group of the six older residents interviewed in the community café still retained a weekly lunch meeting where memories and bonds were upheld and in each interviewee the reminiscences were quickly recalled and with passion for living through the hard life during wartime with their immediate close knit families. In part, they did occasionally visit the Quays but expressed dismay that it was too expensive for them to go regularly and that the Lowry Outlet Mall did not sell things they would want to buy. The Lowry Museum offered more of a sense of community and one interviewee (F68 M27) explained that she was going to join the Quay Club Scheme because she could get membership at a reduced price and then it was free entry.

Conversely, younger participants seemed to know very little about the area and refer to it only as 'Salford Quays'. From the replies gathered, indeed, there was no awareness of the heritage and of the past (cultural and economical) struggle of this part of Salford. To quote the theorist Frederic Jameson, it 
appeared that the local 'contemporary social system ha[d] little by little begun to lose its capacity to retain its own past' (1985: 125). For instance, two participants in their 30s, explained 'This is Salford Quays, I never heard it called Docks before' (F33 M29) and again: ' I know it only as Salford Quays; this is how it is referred to in the media and it is signposted in this way' (M39 M27).

David Harvey (1989; 1997) examines the relationship (or lack of it) between the institutions (e.g. developers, bankers, governments, transport interests) and the surrounding city's inhabitants: he argues that there should be more consideration and linkage between the involved parts, in order to recuperate a sense of local history, traditions, collective memory and identity. This is particularly true in the case of Salford Quays, where the privatised, homogenised, corporate layer has obliterated the older Salfordians lived experiences. On the other hand, a more organic, holistic engagement with the local population could liberate 'an interest in the street and civic architecture as arenas of sociality [and it could permit] new ways of thinking about the relationship between work and living' (Harvey, 1997:2). This, unfortunately, has not happened in the Quays area and affordable housing is beyond the reach of most locals. Nowadays, neighbourhood and community values (which were once at the heart of Salford Docklands) are unknown concepts. When the district first began to be developed in the late 1980s the developers were quick to erect high walls demarking the area and blocking out the relatively close estate of social housing of the 1970's ilk, containing local Salfordians. Salford Quays particularly was being built under the postmodern penchant for fragmentation and ignored the region surrounding it. It became a part of planned design, aiming at professional/business classes and focusing on a strong desire to attract the BBC.

\section{Family and bygone trades}

The second identified theme was 'Family and bygone trades'. From the interviews, in fact, it was possible to understand what made Salford Quays/Docks an effective carrier of cultural memory. Victor Morgan has appropriately pointed out that 'we tend to think of memory as retrospective, as recollection. But [memory is] also prospective' (1999:185). Memories associated with a place, can actually be both the symbols of events and of the achievements (social, economical, cultural) of the place, in a specific historical context. This was evident through our research: when asked about the memories associated with Salford Quays/Docks, participants referred both to personal, family events (both happy and more stressful) as well as to more everyday, general ones (e.g. small boats at the docks, men loading and unloading cargos). They depicted very specific past scenarios, which offered colourful snapshots into the life they used to have in Salford Docks, the trades that used to take place in the area and the local characters that use to populate Salford and its streets.

For example, F69 M44 shared memories about her happy childhood:

'I have a lots of good memories: trips to the park, Saturday mornings at Weaste Picture house; playing games in the street, May Day, dancing around the pole, Whit Walk [...] being in the Rose Queen procession, I was a petal girl'.

F58M3 remembered her teenager's years, when she

'was warned not to go down there and certainly not to go in the pubs. It was where characters like 'Vinegar Vera' plied her trade. My parents occasionally went to pubs down the dock road (Trafford Road) and Broadway on a Saturday night and always had stories to tell of the characters they met. Most of my knowledge of the area was from stories my father told.'

On the other hand, M75 M35 could associate Salford Quays and his early years there only with the war and the displaced way of living of the time. He explained that he could remember:

'living on Middlewood Street [from where] we were blitzed out, three families. We lived the rest of the war in 'Rest Centres' meaning when kids went home from school we could stay in school, otherwise we walked the streets'.

These detailed, personal anecdotes allow the cultural and collective memories of a group of local people to become living stories, which tells of a bygone, 'handmade world, [...] a slow world' (Connerton, 2009: 30); a world made by 'docks, boats, fishing clubs [...] rough and tough, where people [had] to fight to work, [where they had to queue] twice a day [...] and hoped to be picked, just like in the film 'On the Waterfront' (M75 M35). 
From the interviews, indeed, it was possible to picture a very different scenario than the one we are presented with today. Most of the interviewees referred to local places that do not exist anymore (i.e. the pubs down the dock road; 'thousands of 2-up-2-down houses, rows and rows of terraced houses' F67 M3) but also to local characters, which have disappeared with the transformation ('the sailors and the ladies of the evening' F82 M3). The people interviewed have seen the Docks changing greatly throughout the time: from a booming, economically important site, to a post-industrial derelict space and then again into a creative and buzzing cultural quarter.

\section{From cultural narratives to the creative oblivion}

It is unquestionable that our social and cultural environment 'influences the way we mentally process the present [and also] affects the way we remember the past' (Zerubavel, 1999: 81). We tend, in fact, to remember what is familiar to us and what fits with the social context/social group we are and/or were part of. Similarly, we tend to make sense of the present, on the basis of what we know, remember and have experienced (Connerton, 2009; Zerubavel, 1999).

Furthermore, as human beings and in relation to memory construction, we 'mark' the world we have experienced, with landmarks of the past everyday life, tasks or even jobs that have disappeared. Through these landmarks, a social and cultural framework of individual recollections is formed, as well as the signposts for multiple, often nostalgic narratives (Boym, 2002). These signposts (and multiple narratives) become evident only when we are not part anymore of that cultural scenario. Indeed, as Svetlana Boym states: 'one becomes aware of the collective frameworks of memories when one distances oneself from one's community or when that community itself enters the moment of twilight' (2002:54). Within this phenomenon, the act of remembering - in this this paper, understood both as the interpretation of the past and as the selection of the signposts to be remembered - plays an active part. Remembering is a concrete process: 'it is enacted in situations' [...] it is 'the day to day process of how persons create and appropriate stories' (Boym, 2002:253).

Bearing this in mind, we have considered the area of Salford Quays as the cultural and social framework for this study and the hidden collective memories associated with it, as its cultural and social signposts. Although further and more extensive study is needed regarding our subject, the research conducted with the individuals from Salford showed that their present understanding of the Salford Quays area is mediated by a set of experiences (or lack of experiences) and memories. These experiences and memories are part of their individual biographies (e.g. individual Salfordians) but at the same time, they are also part of the history of a group (e.g. age group) or a community (e.g. Salford Quays' residents in the 1970s; Salford Quays' younger professionals) they belong(ed) to. As such, these experiences and memories contribute to defining and shaping a sense of social identity. In this endeavour, the sense of place (and the materiality that goes with it) is very important. This is because ideas, memories and cultural narratives are not context-less but they all need a historical and social framework to be developed and transmitted. However, as our research has shown, the sense of place, even if at a local level and across long established residents, can be fluctuating or even lacking concept.

Our participants (belonging to different age, educational groups and yet all Salfordians) denounced a lack of sense of place and belonging in relation to Salford Quays. People, in fact, tend to remember best only 'what is coloured by emotion'. In the landscape of cultural memory, both personal and communityshared events (like, for example, historical events) can become entangled and therefore meaningful (Boym, 2002); or can become events or places without memory attached to them, hence, insignificant. This is most likely because the contemporary Salford Quays is an aseptic, rather impersonal area, which neither portrays a common local past nor encapsulates local collective and cultural memories (Assmann, 1995). The regeneration strategy, in fact, while aiming at transforming

'Salford Quays and the waterfront [in] a focus of water-related recreation, culture, commerce and living options, [whose] successes will be leveraged to provide benefits and opportunities for neighbouring communities and residents' (Central Salford Board, 2006: 48).

has managed primarily to extinguish both the communicative memories (memories characterized by the everyday rituals and elements of the local residents) and the cultural memories (the ones characterized by its distance from the everyday, which make a place a 'remembrance environment') (Assmann, 1995). Salford Docks, with the little trades and tough living, do not exist anymore. Salford Quays is a working environment, as well as shopping hubs, full of contemporary tall office buildings and waterside apartments (Minton, 2009). However, because of the impersonal feeling of the area, there is almost no willingness, on behalf of the locals, to engage with the dynamic and performative process of recognition, belonging and memory: the narratives of the collective and cultural memories of the industrial past of Salford Docks are being left to the oblivion and new collective and cultural memories of the creative Salford Quays are started being created. 
The publicity both online and in the press continuously reinforce the opportunities available for local people in terms of jobs, entertainment and consumption, but they have the notion that 'one size fits all' and their job opportunities cited for local people generally are in the building trades, which may be of temporary contracts or in servicing the professionals in restaurants, bars and shops. They still do not recognise the importance of community in a holistic sense of a whole range and strata of gender, age and class divides.

\section{Conclusions}

This paper has been dealing with Salford Quays, local cultural identity and at the hidden discourse of local, collective memory. Throughout it, we wanted to make a set of critical observations towards the cultural regeneration strategy implemented in Salford, which we believe is obliterating the local collective and cultural memories. We have been, indeed, trying to question how can the past be brought to the present to support a sense of identity cohesion. Our research has shown that Salford Quays is nowadays a place with little collective and cultural memory. The richness of the local cultural and collective memories has been, in fact, erased and absorbed by a narrative of creative regeneration, which, however, ignores the importance of the local histories.

The older generation surveyed, who understand their important part played in forging an industrial success for Britain, generally had strong memories of the site and the numerous businesses that contributed to both the wealth of the area and of the nation. Having lived through WWII's devastation of the area, due to the canals guiding bombers directly to the site and beyond into Manchester, they also experienced the traumatic decline in employment of the late $20^{\text {th }}$ Century, (Harvey, 1989). Their strong emotional ties are not reflected or given any prominence within the external landscape. The Imperial War Museum North does resonate with their experiences but expresses them through a simulated entertaining experience for parties of schoolchildren, repetitively reproduced at $11 \mathrm{am}$ and $2 \mathrm{pm}$ daily. This ignores the value of lived experience of the local community, post-war and resonating in a great division of cultural experiences within the newly developed Salford Quays site, where prominence is overwritten by the retail businesses serving the professional elite with food and leisure activities (Shaw et al., 2008).

Throughout this paper we have considered issues relating to both the historical significance of Salford Quays as well as its cultural legacy within the local community, questioning whether the past can be brought into the present to support a sense of identity cohesion. It currently seems that priority has been given to reinventing Salford Quays as an innovative creative quarter at the expense of the historical memory of the site. Planners and urban developers are slowly beginning to recognise the obliteration of historical, communal memory that does have importance and we would welcome more acknowledgement of living collective memory being evidenced in the site of Salford Quays.

\section{Endnotes}

1 'Sal' is the old English word for 'Sahl' or 'Sealh', the linguistic root of the modern 'sallow' and 'willow' (Bergin et al., 1975).

2 In addition, the local regeneration and development strategy for the 21st Century has scope for the area of Manchester and Salford to compete internationally for more investment, and jobs, which they claimed should have secured substantial benefits for local residents (Manchester City Council 1994; Marketing Manchester, 2003).

${ }^{3}$ Until then the collection (bequeathed by Laurence Stephen Lowry to the townspeople of Salford) had been kept at Salford Museum and Art Gallery. The Lowry houses two main theatres and a studio space, together with two exhibition areas: the Lowry is considered 'an architectural flagship with a unique and dynamic identity, [which is] rising from the regenerated docklands, [and which has been] designed to reflect the surrounding landscapes and flourishing waterways, in its glass and metallic surfaces' (The Lowry, 2013).

${ }^{4}$ In order to keep the anonymity of the interviewees we have coded them according to their gender, age and postcode.

\section{References}

Assmann, J. \& Czaplicka, J. (1995) Collective Memory and Cultural Identity. New German Critique 65, pp.125-133.

Benson, M. \& Jackson, E. (2013) Place-making and Place Maintenance: Performativity, Place and Belonging among the Middle Classes. Sociology, 47(4), pp. 793-809.

Bergin, T., Pearce, D. N., \& Shaw, S. (eds.) (1975) Salford, A city and its past. Salford: City of Salford Cultural Services Department.

Boym, S. (2002) Future of Nostalgia. New York: Basic Books.

Central Salford Board (2006) The Vision and Regeneration Framework for Central Salford, Salford.

Christophers, B. (2008). The BBC, the creative class, and neoliberal urbanism in the north of England. Environment and Planning A, 40, pp.2313- 2329.

Connerton, P. (2009). How modernity forgets. Cambridge: Cambridge University Press. 
Doron, G. (2000) The Dead Zone and the Architecture of Transgression. City, 4, (2), pp. 246-63.

Fitzgerald, T. (2012) A different kettle of fish in Salford? BBC MediaCityUK row rumbles on as scandal and complaining staff continue. Available at http://mancunianmatters.co.uk/content/31053733-different-kettle-fish-salfordbbc-mediacityuk-row-rumbles-scandals-and-complaining [Accessed 19 December 2013].

Glass, R. (1964) London: aspects of change. London: MacGibbon \& Key.

Gray, E. (2000) Salford Quays: the story of the Manchester Docks. Manchester: Memories.

Harvey, D. (2001) Heritage pasts and heritage presents: temporality, meaning and the scope of heritage studies. International Journal of Heritage Studies, 7 (4), pp. 319-338.

Harvey, D. (1989) The Condition of Postmodernity: An enquiry into the origins of cultural change. Oxford: Blackwell Publishers.

Harvey, D. (1997) The New Urbanism and the Communitarian Trap. Harvard Design Magazine, 1, 2.

Hough, A, (2012) The BBC's $£ 2 m$ London-to-Salford travel bill. Available at http://www.telegraph.co.uk/culture/tvandradio/bbc/9194099/The-BBCs-2m-London-to-Salford-travelbill.html [Accessed December 16, 2013).

Jameson, F. (1985) The Political Unconscious: narrative as a socially symbolic act. Oxon: Routledge.

Manchester City Council (1994) City pride: a focus for the future. Manchester, Salford \& Trafford from the present into the twenty-first century. Manchester: Manchester City Council.

Marketing Manchester (2003) Destination Manchester: a five year tourism strategy 2003-2008. Manchester: Marketing Manchester.

Minton, A. (2009) Ground Control, Fear and happiness in the twenty-first century city. London: Penguin Books Ltd..

Morgan, V. (1999) The construction of civic memory in early modern Norwich, in M. Kwint, C. Breward \& A. Jeremy (eds.) Material Memories. Design and Evocation, New York: Berg Oxford, pp.183-98.

North West Tourist Board: LDR International (1993) Manchester, Salford and Trafford tourism development initiative: a framework for economic development. LDR International, Wigan, North West Tourist Board.

Peel Group (2014) Timeline. Available at http://www.peel.co.uk/aboutus/timeline [Accessed 5 August 2014].

Robson, B. (2002) Mancunian ways: the politics of regeneration. In J. Peck \& K. Ward (eds.) City of Revolution: Restructuring Manchester. Manchester: Manchester University Press, pp. 34-49.

Salford City Council (2005) Salford Education Vision. Available at www.salford.gov.uk/salfordeducationvision.pdf [Accessed 16 December 2013].

Sassen, S. (1991) The Global City: New York, London, Tokyo. Princeton: Princeton University Press.

Shaw, J., Squire-Scholes, B., \& Thurgood, C. (2008) Space and Place - Imperial War Museum North. Journal of Place, Management and Development, 1 (2), pp. 227-231.

Slater, T. (2011) 'Gentrification of the city'. In G. Bridge \& S. Watson (eds.) The New Companion to the City, Malden. Oxford: Blackwell Publishing Ltd., pp:571-585.

The Lowry. (2013) Welcome to the Lowry. Available at http://www.thelowry.com/about-the-lowry/introduction/ [Accessed 16 December 2013].

Tomlinson, V. I. (1974) Salford: an outline of the growth of an industrial town in pictures. Didsbury: Morten.

Watson, S. (2007) History Museums, Community Identity, and a Sense of Place. In S. K. Knell, S. McLeod \& S. Watson (eds.) Museum Revolutions. London: Routledge.

Wedgwood, T. (2009) History in Two Dimensions or Three? Working Class Responses to History. International Journal of Heritage Studies, 15 (4), pp. 277-297.

Wheeler, V. \& Carson, J. (2005) A haunting: an interdisciplinary event. Manchester: The Land.

Zerubavel, E. (1999) Social Mindscapes. An invitation to Cognitive Sociology. New York: Harvard University Press.

\section{Acknowledgements}

The authors would like to thank Angie McVeigh, Invigilator at The Lowry, and all the people of Salford who took part to this research shared their memories and views and completed our questionnaires. 